\title{
Consonant articulation and vocabulary size: Twins versus singletons
}

\author{
F. Nihan KETREZ (D) \\ Istanbul Bilgi University, Turkey \\ Address for correspondence: F. Nihan Ketrez Istanbul Bilgi University Dept. of English Language and \\ Literature Eski Silahtaraga Elektrik Santrali Kazim Karabekir Cad. No: 2/13 34060 Eyüpsultan ISTANBUL \\ TURKEY. E-mail: ketrez@gmail.com
}

(Received 1 July 2020; revised 5 April 2021; accepted 26 July 2021; first published online 2 September 2021)

\begin{abstract}
Turkish-speaking dyzygotic twins $(n=21)$ and singletons $(n=23)$ were tested through a standard articulation test to observe whether their consonant articulations were related to their vocabulary sizes, recorded through CDI forms, at age 3;0. Twins were observed to lag behind their singleton peers and performed below the norm level in their production. Vocabulary size failed to predict twins' articulation scores although it predicted the scores of the singleton group. The results suggested that articulation was not related to vocabulary size in twins. Exposure to sibling language was discussed as an alternative risk factor.
\end{abstract}

Keywords: Consonant articulation; twins; Turkish; CDI; vocabulary size

\section{Introduction}

Twins are observed to achieve the milestones of language development at a slower pace when compared to their singleton peers (Conway, Lytton \& Psych, 1980; Mogford, 1993; Rutter, Thorpe, Greenwood, Northstone \& Golding, 2003 among others). They speak in shorter sentences, and have a smaller lexicon size as well as an overall less complex language (Conway et al., 1980; Hay, Prior, Collett \& Williams, 1987; Mogford, 1993; Gücüyener, Arhan, Soysal, Ergenekon, Turan, Onal, Koç, Turkyilmaz \& Atalay, 2011; Rice, Zubrick, Taylor, Gayán \& Bontempo, 2014). They are also reported to have a greater tendency for speech disorders (Dodd \& McEvoy, 1994; Lewis \& Thompson, 1992) and produce a lesser amount and diversity of gestures (Ozturk, Pınar, Ketrez \& Özçalışkan, 2021). Differences observed in twins' language devlopment are attributed to biomedical reasons such as low birth weight and preterm birth (Stromswold, 2006) and/or psychosocial or environmental disadvantages (e.g., the amount and quality of input language) that are associated with twinning (Lytton, Conway \& Suave, 1977; Stafford, 1987). Different subareas of language develop interdependently. Vocabulary and articulation are such interdependent areas (e.g., 
Smith, McGregor \& Demille, 2006) but their development by different populations of children acquiring typologically different languages have not been studied. This study aims to contribute to the discussion of language development of twins in comparison to singletons with consonant articulation and vocabulary data from Turkish, a language that has not been explored from this perspective before.

\section{Perinatal risk factors and social environment of twins vs. singletons}

Twins are special not only because of perinatal conditions they experience but also because of their unique social environments that have potential impacts on their language acquisition.

Because twins are more likely to be born preterm (before 37 weeks of gestation), complications or disadvantages due to preterm birth interfere with their development. Briscoe, Gathercole and Marlow (1998), for example, report that the preterm children (born before 32 weeks of gestation) they studied $(n=26$, between $4 ; 0-6 ; 0)$ performed poorly in all of the language measures that they tested, including vocabulary, expressive language and phonological short term memory. Jennische and Sedin (1999) report that gestational age correlates with preterm children's language performance as late as 6;0; children who were born between 28-31 weeks perform more poorly than children who were born between 32-36 weeks. Auditory discrimination, articulation and sentence imitation were affected more frequently than other language abilities. Luoma, Herrgård, Martikainen and Ahonen (1998) compare five-year old preterm (born before 32 weeks of gestation) and full term children in terms of their language comprehension and production among other measures including IQ scores, and observe that preterm children lag behind their full term peers in all of the areas. When the preterm children with major neurological disabilities were excluded, the difference between the preterm and control children was reduced but the two groups were still different in terms of object naming time. In general, preterm children needed more time to name objects but had only a few differences in the number of tokens that they named correctly. On the other measures, the statistical difference between the two groups was maintained only when the children with neurological disabilities were included. This was a finding that suggested that the reason behind poor language performance of preterm children was related to the neurological deficits due to preterm birth. With a similar rationale, it was argued that twins were delayed in language development because of these disadvantages that resulted in similar delays in singleton preterm children with similar biomedical conditions (Ganger, 2003; Stromswold, 2006). Lung, Shu, Chiang and Lin (2009) reported that the difference they observed between singletons' and twin children's development disappeared when birth weight and prematurity were controlled, therefore supporting the earlier findings that biomedical factors played a crucial role on children's development. In a more recent study on Italian-speaking preterm and fullterm children's language development, Capobianco and Cerniglia (2017) found that preterm children without any neurological damage were slower at language development (word comprehension and gesture) when compared to their full term control peers, but both groups were performing within the normal range.

Disadvantages due to prematurity can eventually be overcome and environmental factors play a more significant role in later developmental phases (Lee \& Barratt, 1993). A less than ideal home environment due to less time spent with care-givers, less direct speech and triadic interaction pattern were reported as potential reasons for twins' differences. Tomasello, Mannle and Kruger (1986), for example, reported 
that although mothers of twins did not produce less speech or spent less time with their children, they had less speech directed to each individual child and fewer joint attention situations, which were important as they provided a child with an enviroment that facilitated language learning. Similarly, Stafford (1987) studied the conversational styles of mothers of twins and singletons with elder siblings and observed that twin mothers were less responsive and their speech included fewer conversation elicitations. Mothers' conversation style correlated with their children's behavior in conversations. A recent study reported that the differences between twin and singleton parents' speech directed to their children were reflected in their use of gestures as well. The parents of singletons were observed to provide a greater amount, diversity, and complexity of gestures than parents of twins in their interactions with their children (Pınar, Ozturk, Ketrez \& Özçalışkan, 2021). So-called "secret twin language" or "private" language that twin siblings develop collectively result in an even slower development of language and could be attributed to the social disadvantages due to twin home environments (Bishop \& Bishop, 1998; Dodd \& McEvoy, 1994; Thorpe, Greenwood, Eivers \& Rutter, 2001).

In summary, having a twin sibling, growing up in a twin home environment and being a preterm infant all contribute to an increased risk of slower language development. While in some children these disadvantages result in serious delays, in some others they appear as mild differencess within the normal range.

\section{Speech development of twins vs. singletons}

Slower development of articulation, just like other areas of language, is common in twins (McEvoy \& Dodd, 1992). In one of the earliest studies on twins, Day (1932) reported more incomprehensible responses in twins which could be related to articulation problems. Conway et al. (1980) observed that mothers of twins rated their children's speech less mature. Koch (1966) reported that half of the twins in their study had poor articulation. In Davis (1937), too, twins' articulation was reported as inferior in five-year-olds. In one of these early studies on the articulation of twins vs. singletons, Mathenny and Bruggeman (1972) reported that the mean scores of twins were significantly lower than singletons in the standard articulation test they conducted. Their study was based on the 1960 version of Templin-Darley Screening Test for Articulation (Templin \& Darley, 1960) conducted on 263 twin and 94 singleton children between 4;0-8;0. The study also reported that the birth order and socio-economic status influenced both the twins and the singletons but twins had further disadvantages due to these factors. In addition to slower language development, disordered speech was more likely to be observed in twins (Dodd \& McEvoy, 1994; Lewis \& Thompson, 1992). Boys (boy-boy twins) were reported to have more articulation problems than girls (Hay et al., 1987, among others). McEvoy and Dodd (1992) observed that the 19 sets of twins they investigated lagged behind their singleton peers in syntax and phonology measures. However, although they performed poorly when compared to the singleton group, twins still fell within the normal range. So the difference between the twins and singletons did not always mean that the twins were delayed.

\section{Articulation and vocabulary size}

Articulation of children at a particular age was observed to be related to their overall language development: in particular, the vocabulary size (Kehoe, Chaplin, Mudry \& 
Friend, 2015; Kehoe \& Havy, 2019; Paul \& Jennings, 1992; Petinou \& Okalidou, 2006; Stoel-Gammon, 1991, 2011; Smith et al., 2006; Schwarz, Burnham \& Bowey, 2006, among others). Children with large vocabularies had more advanced phonological systems, and later talkers had fewer accurate consonant productions. Smith et al. (2006), for example, compared children aged 24 months with precocious lexicons, children of the same chronological age with average lexicon and 30-month-old children with average lexicon. They observed that 'lexically precocious' children had larger phonetic inventories than those with average lexicons at 24 months, and phonological development was more closely related to children's lexicon size than chronological age. The relationship between lexical development and child vocalizations was observed to be bidirectional, as well. That is, large vocabularies signaled more advanced articulations, and children with more advanced articulations had larger vocabularies (Rescorla \& Ratner, 1996).

Twins, when compared to singletons, were observed to have a smaller vocabulary size. Early studies (Day, 1932, for example) observed that twins produced their first words later than singletons and had an overall smaller number of verbs, adjectives, pronouns and conjunctions in their vocabulary, although no difference was observed in nouns. Koch (1966) observed that $29 \%$ of the twins had a delay for their first words. Mittler (1970) reported that first words emerged later than 18 months in the speech of $30 \%$ of the twins and that vocabulary difference was persistent up to five years. Davis (1937) also reported that twins continued using fewer different word types in later ages.

\section{The present study}

The goal of this study is to investigate whether Turkish speaking twins lag behind their singleton peers in terms of their consonant articulation even when neonatal characteristics are controlled. Earlier studies discussed above predicted a difference within a normal range but not necessarily a delay in twins' articulation, especially when the two groups are balanced in terms of their birth weight and gestational age. Having shown that twins lag behind in terms of their consonant articulation, the study further aims to investigate whether children's articulation could be related to their vocabulary size, which was reported to be a related factor on the acquisition of articulation (e.g., Rescorla \& Ratner, 1996; Smith et al., 2006). Finally, the articulation scores of twins were compared to the scores of their siblings to observe a potential influence of their exposure to each others' speech on their articulation.

Turkish has 24 consonant phonemes (see Appendix A for the list of Turkish consonant phonemes and their examples in different positions). Normally developing Turkish speaking children are observed to follow the universal paths in their development of these phonemes (Topbaş, 1997, 2006b, 2007; Topbaş \& Dinçer, 2002 among others). At or before age 3;0 most consonants are produced at least in one position. In terms of the location of phonemes in words, word final and word initial positions are easier than within word positions. Phonemes tend to be produced with more errors within words, both in the syllable final and syllable initial positions (Topbaş, 2006b). There has been no study that focused specifically on the role of twinning on articulation in Turkish speaking children. Topbaş and Ünal (2010) report a case study conducted on six-year-old monozygotic twin girls who were diagnosed with a speech disorder but discuss their development in relation to treatment types. The present study is the first one that discusses consonant 
Table 1. Participants, their birth weight, gestational age and chrononological age (mean scores).

\begin{tabular}{lccc}
\hline Groups & Birth weight & Gestational age & Chronological age \\
\hline Singletons ( $\mathrm{n}=23)$ & $\begin{array}{c}2860.21 \text { grams } \\
\text { (SD: } 1084.01)\end{array}$ & 36.47 weeks (SD: 5.17) & $\begin{array}{c}36.21 \text { months } \\
\text { (SD: .671) }\end{array}$ \\
\hline Twins $(n=21)$ & $\begin{array}{c}\text { 2333.52 grams } \\
\text { (SD: 449.98) }\end{array}$ & 35.47 weeks (SD: 2.35) & $\begin{array}{c}36.04 \text { months } \\
\text { (SD: } 2.71)\end{array}$ \\
\hline
\end{tabular}

articulation in relation to twinning and also in relation to the role of vocabulary size in Turkish speaking children.

\section{Method}

\section{Participants}

23 singletons (14 male, 9 female), who do not have a sibling, and 21 twins (12 male, 9 female), who have a twin sibling, participated in the study. They were all monolingual children from families with middle socio-economic status living in İstanbul. Written consent was obtained from the parents prior to their participation in the study. All participants were observed to be normally developing according to the Turkish adaptation of Denver-II Developmental Screening Test (Yalaz, Anlar \& Bayoğlu, 2011). All twins were dyzygotic twins, reported as such by their parents, and had either same- or different-sex siblings. Both co-twins were tested individually but because co-twins did not provide independent data, only one of them (the one with the bigger birth weight) was included in the analyses. The score of the other co-twin was used as the sibling score in the follow-up analysis that focused on the predictability of the twins' articulation scores based on their sibling articulation scores.

The mean birth weight, gestational age as well as the chronological age of the participating children are shown in Table 1 . Independent samples $t$-tests conducted individually on their chronological age, gestational age and birth weight did not show any difference in their gestational and chronological ages $(t(42)=.957, p=.344$, $t(42)=.201, p=.842$, respectively). Despite the efforts to balance the two groups in terms of their birth weight by including relatively low birth weight children (smaller than 2500 grams) in the singleton group and by including the co-twin with the bigger birth weight in the twin group, the singleton group still had a bigger mean birth weight $(t(42)=2,559, p<.05)$. Thus it was necessary to control for the birth weight in the statistical analyses.

\section{Procedure}

A standardized articulation test (Sesletim Sesbilgisi Testi) developed by Topbaş (2006a) was conducted at the child's home, by a female research assistant, who was a graduate student in linguistics. It was a picture-naming task where children named the objects that were shown to them one by one in a booklet. The booklet had 93 hand-drawn pictures of objects whose names had Turkish phonemes in particular positions in words (see Appendix A). For example, to test the articulation of $/ \mathrm{k} /$, four words were used: $k u s ̧$ 'bird' that had $/ \mathrm{k} /$ in the word initial, syllable initial position, şap.ka 'hat' and a.yak.ka.bı 'shoe' that had $/ \mathrm{k} /$ within word, syllable initial and syllable final positions respectively, and ku.lak 'ear' where $/ \mathrm{k} /$ was tested for word final, syllable 
final position. In addition to the consonants, the test included seven consonant clusters which were tested mainly in the word final position, where they mostly occurred in the language.

The sessions were audio-recorded and target words were later transcribed and coded by listening to the recordings. Children's words were marked as correct or incorrect by a coder. A second coder coded a randomly selected $20 \%$ of the data and the reliability of the coders was $86 \%$ (Cohen's kappa $=.86$ ). Both coders were native speakers of Turkish and graduate students in linguistics trained in child articulation. When children produced the target phoneme in the target position, and when it was phonetically correct, it was marked as a "correct" production. When the phoneme was not produced phonetically correctly or when it was not produced in the target position, the utterance was marked as "incorrect". For example, when the child produced the word radyo /rad.jo/ 'radio' as /jad.do/, the production of the phoneme /d/ was considered a correct production, whereas the production of the word as /ja:.do/ was considered incorrect because the phoneme was not produced in the target position. Similarly, if the child produced the word helikopter /he.li.kop.ter/ as /op.ti/, it was marked as correct because /p/ is produced correctly in the target position. Total numbers of errors (incorrect articulations) were recorded as articulation scores.

In order to test whether children's articulation scores were related to their lexicon sizes, the Turkish adaptation of McArthur Bates CDI-forms were used (Acarlar, Aksu-Koç, Küntay, Maviş, Sofu, Topbaş \& Turan, 2009). Turkish-CDI was a vocabulary check-list of words and grammatical morphemes. Only the vocabulary part that was composed of 711 words was used in this study. CDI-forms were filled out by the parents or other primary care givers of the children during the same session or within the same week when the children participated in the articulation tests. Total number of productive vocabulary was counted and recorded as a CDI score. Individual forms were filled out by the same care-giver for each co-twin.

\section{Results}

\section{Consonant articulation by twins vs. singletons}

The difference between the twins and the singletons was examined in two different analyses. In the first one, the mean articulation scores (error scores) of the two groups was compared. The mean articulation scores and their range are presented in Table 2, along with the vocabulary scores that will be discussed in the next section. The ANCOVA conducted on the error scores, with the birth weight as a controlled variable, showed that twins' mean score (the error score) was significantly higher than that of the singletons' $(F(2,42)=2.521, p<.05)$.

It is important to acknowledge that although this comparison showed that twins and singletons were different, it did not necessarily show that twins were delayed. It is possible that the two groups were different but at the same time both groups' scores fell within the normal range, or the singletons' error scores might be exceptionally high. A closer examination of the articulation scores showed that in the singleton group six $(26 \%)$ and in the twin group 10 children $(47 \%)$ had scores lower than the norm score determined by Topbaş (2006a). In the singleton group one child, in the twin group four children had an articulation age of 2;0 (one year difference) according to the norm. In the singleton group, seven children (30\%) had an articulation age of 4;0 (one year ahead). In order to check whether twins were not only different when compared to the control group but also behind their age, the 
Table 2. Articulation scores (errors) and CDI (vocabulary) scores

\begin{tabular}{lllll}
\hline Groups & \multicolumn{1}{c}{$\begin{array}{c}\text { Articulation } \\
\text { mean }\end{array}$} & $\begin{array}{c}\text { Articulation } \\
\text { Range }\end{array}$ & $\begin{array}{c}\text { CDI Score } \\
\text { (Vocabulary) }\end{array}$ & CDI Range \\
\hline Singletons $(n=23)$ & 24.86 (SD: 15.97$)$ & $2-66$ & 609.95 (SD: 136.80$)$ & $291-711$ \\
\hline Twins $(n=21)$ & $37.42($ SD: 17.06$)$ & $13-75$ & 591.57 (SD: 171.40$)$ & $58-711$ \\
\hline
\end{tabular}

mean error scores of each group were compared to the norm score (28 errors at 36 months) reported for age 3;0 by Topbaş (2006a). A one-sample $t$-test conducted on the singletons' articulation scores showed that singletons' mean articulation score was not different from the norm $(t(22)=-1.268, p=.218)$. So, we could see that the sample of singleton participants were normal according to their age. The same test conducted on the mean scores of the twins showed that twins' mean score was significantly lower than the norm $(t(20)=2.385, p<.05)$. These results showed that twins were not only different from the singleton controls in the present study, they were also behind according to the norm.

In summary, twins and singletons were different in terms of their articulation scores at 3;0, and twins were different not only when compared to the singleton control group of the present study, but also according to the norm scores determined for Turkish (Topbaş, 2006a).

\section{Articulation and vocabulary size}

The third analysis was conducted to see whether children's consonant articulation can be related to their vocabulary sizes. Table 2 above shows the articulation scores of twin and singleton groups together with their vocabulary scores based on their CDI reports. In both groups, the highest vocabulary score was 711 words, which was the maximum number of words possible. Although the maximum scores were the same, and the mean scores were similar in groups, the lowest score was 291 words in the singleton group and 58 words in the twin group.

Regression analyses were conducted on singleton and twin groups separately. In the case of the singleton children, it was observed that the CDI scores at 3;0 predicted their articulation scores $(b=-.735, t(21)=-4.961, p<.001)$. Twins' results, however, were different. The CDI scores of twins did not predict their articulation scores $(b=-.288, t(20)=-1.310, p=.206)$. In other words, those twins who had large $(\mathrm{r})$ vocabularies did not necessarily have better articulation at age 3;0. Their articulation pattern did not seem to result from factors related to their language level (their vocabulary size, in particular) that could potentially intervene with their articulation development.

\section{A follow-up analysis: Exposure to sibling language as an environmental factor}

Since neither neonatal disadvantages (i.e., early gestational age and low birth weight) nor vocabulary sizes were found to predict or explain twin children's weaker articulation performance in this study (birth weight was controlled for while vocabulary size was explicitly tested), we conducted a follow-up analysis comparing the twins' articulation performance to that of their siblings. The goal of this follow-up analysis was to understand why the vocabulary size did not predict the consonant articulation scores of the twins, while it predicted that of the singletons. 
Table 3. Mean articulation (error) scores of twins and their siblings

\begin{tabular}{llc}
\hline Groups & Mean articulation score & Range \\
\hline Twins $(n=21)$ & $37.42($ SD: 17.06$)$ & $13-75$ \\
\hline Siblings $(n=21)$ & $35.28($ SD: 15.64$)$ & $8-75$ \\
\hline Mean Difference & 2.14 & $0-36$ \\
\hline
\end{tabular}

In order to test whether twins' articulation scores could be related to their exposure to their siblings' speech, the articulation scores of the two siblings were compared.

Table 3 shows the mean articulation scores of the twins and their siblings along with the mean difference and the range of scores. The comparison showed that the articulation scores of the siblings were similar to that of their co-twins with a difference ranging from 0 to 36 errors (mean difference of 2.14 errors). The lowest articulation scores in both groups (13 in twins and 8 in siblings) belonged to the same twin dyad. The two highest articulation scores (75 and 66), as well, belonged to the same twin dyads (75-75 in one dyad, and 75-66 in another one). Three twins had the same articulation scores as that of their siblings. The difference between the dyads, when there is any, ranged from 1-to-36 and in half of these dyads, the twins had higher scores than their siblings.

A regression analysis conducted on the siblings' articulation scores showed that the sibling articulation scores predicted the twins' articulation scores $(b=.685, t(19)=$ 4.095, $p<.005)$ - that is, those co-twins whose articulation scores were high (those that had more errors), had siblings who had relatively poor articulation. In other words, those children with poor articulation were the ones who were exposed to more articulation errors through their siblings.

\section{Discussion}

The analyses have shown that Turkish speaking twins lagged behind their singleton peers in terms of their consonant articulation at age 3;0. They were also behind according to the norm reported in Topbass (2006a). A closer examination of the articulation scores showed that although twins had a lower score as a group, their individual articulation scores showed a large range. $47 \%$ of the twins had scores below the scores expected for their chronological age. So there were twin children who were not lagging behind in terms of their articulation skills by age 3;0, although the twin group as a whole was observed to be behind the singletons. There also were twins who performed better than an average singleton child. In the singleton group, too, there were children whose articulation scores were lower than the norm and lower than some twins' scores.

The difference observed between the two groups could not be related to peri-/ postnatal factors (birth weight and gestational age) as these factors were controlled in the present study. Therefore, the present findings suggested that the difference observed between twins and singletons did not necessarily result from disadvantages due to preterm birth or low birth weight.

The twin results could not be related to twins' vocabulary size either. In the singleton group, children with larger vocabularies had better articulation scores, just as it was observed in the literature on other languages (e.g., Smith et al., 2006) but a similar 
result was not found for the twins. In order to account for this discrepency between the results of twins and singletons, a follow-up analysis was conducted on the sibling articulation scores.

A potential twinning factor that could affect twins' articulation pattern could be twins' exposure to their co-twins' speech. In contrast to singletons and children with elder siblings, a child with a twin sibling tyically spends more time with a communication partner, whose speech has less than ideal articulation characteristics. Twins' extended exposure to each others' immature speech was discussed as a possible factor contributing to the development of so-called secret twin languages (Bishop \& Bishop, 1998; Dodd \& McEvoy, 1994). Dodd and McEvoy (1994) show that such twin languages are based on twins' shared misarticulations and common or shared non-adult-like phonological systems. Shared or similar phonological systems are not characteristics of only those twins whose languages are interpreted as a "secret code". Those co-twins who do not develop a special twin language are reported to have similar, though not completely alike, developmental patterns as well (Ingram, Dubasik, Muñoz-Liceras \& Fernandez-Fuertes, 2011; Ingram \& Dubasik, 2014). Although the results in the present study do not necessarily show that twins' articulation difference is caused by their exposure to their twin sibling's language, the results are consistent with those studies that report similarity or intertwined articulation systems of co-twins. There are also studies that show that twin siblings may have very different phonological systems. Clements and Fee (1994), for example, report a case study on a pair of dyzygotic twins (examined at $6 ; 1$ and 7;6), one of which has been diagnosed as being language impaired and had a delay of four-to-five years, while the other one was developing normally. Such exceptional cases are not comparable to the cases reported here because all the participants in the present study were normally developing children who have not been diagnosed with any speech disorder. It is likely that such big differences are observed when one of the co-twins has a special developmental condition.

It is important to acknowledge that the similarity we observed in this study was based on a single articulation score calculated on the basis of correct vs. incorrect articulations so the "similarity" represented a similar degree of inaccuracy in siblings' speech. Qualitative data on the types and patterns of errors children made were not analyzed to evaluate the exact nature of the similarity or inaccuracy. Siblings may have similar or totally different types of inaccurate articulations. Further analyses of the error types are necessary to confirm the similarity of twins' articulation patterns.

The similarity observed between the articulation scores of co-twins is predicted by the argument that twins' exposure to each other's speech for an extended period of time intervenes with their consonant development, supporting the argument that the environmental factors intervene with their language acquisition. However, it is also important to acknowledge that the similarity observed in siblings' articulations could also be due to their shared genes rather than (or along with) their shared environment or exposure to each other's speech. Earlier studies conducted on different types of twins showed that monozygotic twins, who share $100 \%$ of their genes, have higher similarity than dyzygotic twins, who typically share $50 \%$ of their biological make-up; and dyzygotic twins have higher similarity than non-twin siblings (Ingram et al., 2011; Ingram \& Dubasik, 2014). This pattern shows that the similarity of children's speech systems is not only due to environmental factors, but could also be related to their shared genetics. Along the same line, Locke and Mather (1989) observed that monozygotic twins are more likely to misarticulate the 
same sounds in an articulation test, than dyzygotic twins. Dyzygotic twins share more errors than unrelated children. Similarly, monozygotic twins are more likely to understand each other's (mis)articulations (Dodd \& McEvoy, 1994). The present results, when considered along with these findings, cannot be argued to present a conclusive evidence for the environmental factors on language development, although they are consistent with such an argument. Further research needs to be conducted in order to understand the role of the home environment as a twinning factor in general, and sibling influence on language development in particular. A comparison of the speech patterns of monozygotic vs. dyzygotic twins as well as the non-twin siblings would provide insights into this issue. In addition, a more detailed observation of the nature and the amount of input language twins receive from their siblings as well as other people around their environment could contribute to a better understanding of the possible role of environmental factors on their speech development.

Different subdomains of language are influenced by each other during the language acquisition period. Vocabulary size and articulation are two such areas that are observed to develop interdependently. The present study suggested that in the case of special populations, such as twins, such interdependent relationships may be blurred due to other (perinatal or environmental) factors. Further research with larger sample sizes and with more detailed analyses of various language subdomains is necessary for a better understanding of the nature of the language acquisition experience of different populations of children.

Acknowledgments. This study was supported by TUBITAK (Turkish Scientific and Technical Research Council), grant number 111K270 (PI: F. Nihan Ketrez Sözmen). I would like to thank Seyhun Topbaş and Ayhan Aksu-Koç for providing me with the articulation test material and the Turkish CDI forms, and the research assistants, Nihal Meriç, Funda Kamiloğlu and Aslı Özkul, for their contribution to the data collection and transcription phases of the study.

\section{References}

Acarlar, F., Aksu-Koç, A., Küntay, A. C., Maviş, İ., Sofu, H., Topbaş, S., \& Turan, F. (2009). Adapting MB-CDI to Turkish: The first phase. In S. Ay, Ö. Aydın., İ. Ergenç, S. Gökmen, S. İşsever, \& D. Peçenel (eds.), Essays on Turkish linguistics: Proceedings of the 14th International Conference on Turkish Linguistics, August 6-8, 2008. Harrassowitz Verlag: Wiesbaden, Germany.

Bishop, D. V., \& Bishop, S. J. (1998). Twin language: A risk factor for language impairment? Journal of Speech, Language and Hearing Research, 41(1), 150-160.

Briscoe, J., Gathercole, S. E., \& Marlow, N. (1998). Short-term memory and language outcomes after extreme prematurity at birth. Journal of Speech Language and Hearing Research, 41, 654-666.

Capobianco, M., \& Cerniglia, L. (2017). Early language development in preterm children without neurological damage: a longitudinal study. F1000 Research 6: 2169.

Clements, A., \& Fee, E. J. (1994). An intra-twin phonological study: Phonologies of a SLI twin and her normally developing brother. First Language, 14, 213-231.

Conway, D., Lytton, H., \& Psych, F. (1980). Twin-Singleton Language Differences. Canadian Journal of Behavioral Science, 12(3), 264-271.

Davis, E. A. (1937). The development of linguistic skill in twins, sinlgetons, and sibs, and only children from 5-10. University of Minnesota Institute of Child Welfare, Monograph 14.

Day, E. J. (1932). The development of language in twins. Child Development, 3, 179-199.

Dodd, B., \& McEvoy, S. (1994). Twin language or phonological disorder. Journal of Child Language, 21(2), 273-289.

Ganger, J. (2003). Twins and language development: An Overview. E-article. URL: http://www. speechpathology.com. 
Gücüyener, K., Arhan, E., Soysal, A. S., Ergenekon, E., Turan, O., Onal, E., Koç, E., Turkyilmaz, C., \& Atalay, Y. (2011). Language assessment of non-handicapped twins at 5 years of age. Pediatric International, 53(6), 944-949.

Hay, D. A., Prior, M., Collett, S., \& Williams, M. (1987). Speech and language development in preschool twins. Acta Geneticae Medicae et Gemellologiae, 36(2), 213-223.

Ingram, D., Dubasik, V., Muñoz-Liceras, J., \& Fernandez-Fuertes, R. (2011). Early phonological acquisition in a set of English-Spanish bilingual twins. In Implicit and Explicit Language Learning, C. Sanz \& R. Leow (eds), (pp. 195-205). Washington DC: Georgetown University Press.

Ingram, D., \& Dubasik, V. L. (2014). Sibling rivalry: Comparing phonological similarity between twin and non-twin siblings. In A. Farris-Tremble \& J. Barlow (eds.), Perspectives On Phonological Theory And Development: In Honor Of Daniel A. Dinnsen Language Acquisition and Language Disorders 56 (pp. 53-70). Amsterdam: John Benjamins.

Jennische, M., \& Sedin, G. (1999). Speech and language skills in children who required neonatal intensive care. II. Linguistic skills at $61 / 2$ years of age. Acta Paediatrica, 88, 371-383.

Kehoe, M., Chaplin, E., Mudry, P., \& Friend, M. (2015). The development of phonological skills in late and early talkers. Rééducation Orthophonique, 263, 61-85.

Kehoe, M., \& Havy, M. (2019). Bilingual phonological acquisition: The influece of language-internal, language external and lexical factors. Journal of Child Language, 46(2). 292-333.

Koch, H. L. (1966). Twins and twin relations. University of Chicago Press, Chicago, IL.

Lee, H., \& Barratt, M. S. (1993). Cognitive development of preterm low birth weight children at 5 to 8 years old. Journal of Developmental and Behavioral Pediatrics, 14(4): 242-249.

Lewis, B. A., \& Thompson, L. A. (1992). A study of developmental speech and language disorders in twins. Journal of Speech \& Hearing Research, 35(5), 1086-1094.

Locke, J., \& Mather, P. L. (1989). Genetic factors in the ontogeny of spoken language: Evidence from monozygotic and dizygotic twins. Journal of Child Language 16(3). 553-559.

Lung, F. W., Shu, B. C., Chiang, T. L., \& Lin, S. J. (2009). Twin-singleton influence on infant development: A national birth cohort study. Child care health and development 35(3). 409-418.

Luoma, L., Herrgård, E., Martikainen, A., \& Ahonen, T. (1998). Speech and language development of children born at $<$ or $=32$ weeks' gestation: a 5-year prospective follow-up study. Developmental Medicine and Child Neurology, 40(6), 380-387.

Lytton, H., Conway, D., \& Suave, R. (1977). The impact of twinship on parent-child interaction. Journal of Personality and Social Psychology, 35, 97-107.

Mathenny, A. P., \& Bruggeman, C. (1972). Articulation proficiency in twins and singletons from families of twins. Journal of Speech, Language, and Hearing Research, 15, 845-851.

McEvoy, S., \& Dodd, B. (1992). The communication abilities of 2-to 4-year old twins. European Journal of Disorders of Communication, 27(1). 73-87.

Mittler, P. (1970). Biological and social aspects of language development in twins. Developmental Medicine and Child Neurology, 12, 741-757.

Mogford, K. (1993). Language development in twins. In D. Bishop \& K. Mogford (eds.), Language Development in Exceptional Circumstances. (pp. 80-95). New York: Psychology Press.

Ozturk, S., Pınar, E., Ketrez, F. N., \& Özçalışkan, Ş. (2021). Effect of sex and dyad composition on speech and gesture development of singleton and twin children. Journal of Child Language 1-19. doi:10.1017/ S0305000920000744.

Paul, R., \& Jennings, P. (1992). Phonological behavior in toddlers with slow expressive language development. Journal of Speech, Language, and Hearing Research, 35, 99-107.

Petinou, K., \& Okalidou, A. (2006). Speech patterns in Cypriot-Greek late talkers. Applied Psycholinguistics, 27, 335-53

Pınar, E., Ozturk, S., Ketrez, F. N., \& Özçalışkan, Ş. (2021). Parental speech and gesture input to girls vs. boys in singletons and twins. Journal of Nonverbal Behavior, 45, 297-318. https://doi.org/10.1007/ s10919-020-00356-w

Rescorla, L. A., \& Ratner, N. B. (1996). Phonetic profiles of toddlers with specific expressive language impairment (SLI-E). Journal of Speech, Language, and Hearing Research, 39(1), 153-165.

Rice, M., Zubrick, S., Taylor, C., Gayán, J., \& Bontempo, D. (2014). Late language emergence in 24-month-old twins: Heritable and increased risk for late language emergence in twins. Journal of speech, language, and hearing research, 57(3), 917-928. 
Rutter, M., Thorpe, K., Greenwood, R., Northstone, K., \& Golding, J. (2003). Twins as a natural experiment to study the causes of mild language delay: I: design; twin-singleton differences in language, and obstetric risks. Journal of Child Psychology and Psychiatry, 44, 326-341.

Schwarz, I., Burnham, D., \& Bowey, J. A. (2006). Phoneme Sensitivity and vocabulary size in $2 \frac{1}{2}-$ to 3-year-olds. In P. Warren \& C. I. Watson (eds.), Proceedings of the 11th Australian International Conference on Speech Science \& Technology (pp. 142-147). Aukland, New Zealand: Univ. of Auckland, New Zealand / Australian Speech Science \& Technology Association Inc.

Smith, B. L., McGregor, K. K., \& Demille, D. (2006). Phonological development in lexically precocious 2-year-olds. Applied Linguistics, 27(3), 355-375.

Stafford, L. (1987). Maternal Input to Twin and Singleton Children Implications for Language Acquisition. Human Communication Research, 13(4). 429-462.

Stoel-Gammon, C. (1991). Normal and disordered phonology in two-year-olds. Topics in Language Disorders, 11, 21-32.

Stoel-Gammon, C. (2011). Relationship between lexical and phonological development in young children. Journal of Child Language, 38, 1-34.

Stromswold, K. (2006). Why aren't identical twins linguistically identical? Genetic, prenatal and postnatal factors. Cognition, 101(2), 333-384.

Templin, M. C., \& Darley, F. L. (1960). The Templin-Darley Tests of Articulation: A Manual and the Discussion of the Screening and Diagnostic Tests. Bureau of Educational Research and Service, Extension Division, State University of Iowa.

Thorpe, K., Greenwood, R., Eivers, A., \& Rutter, M. (2001). Prevalence and development course of "secret language." International Journal of Language and Communication Disorders, 36, 43-62.

Tomasello, M., Mannle, S., \& Kruger, A. C. (1986). Linguistic environment of 1- to 2- year-old twins. Developmental Psychology, 22(2), 169-176.

Topbaş, S. (1997). Turkish children's phonological acquisition: Implications for phonological disorders. European Journal of Disorders of Communication, 32, 377-397.

Topbaş, S. (2006a). Türkçe Sesletim-Sesbilgisi Testi: Geçerlilik-Güvenirlik ve Standardizasyon Çalışması. Türk Psikoloji Dergisi, 21, 39-56.

Topbass, S. (2006b). Does the speech of Turkish-speaking phonologically disordered children differ from that of children speaking other languages? Clinical linguistics and phonetics, 20(7-8), 509-522.

Topbaş, S. (2007). Turkish speech acquisition and disorders. In S. McLeod (ed.), The international guide to speech acquisition. (pp. 566-579). Cliftonpark, NY: Thomson Delmar Pub.

Topbaş, S., \& Dinçer, B. (2002). Universal and language specific aspects of variability in phonological patterns. Paper presented at IASCL-SRCLD Conference, 16-21 July, 2002. University of Wisconsin, Madison.

Topbaş, S., \& Ünal, O. (2010). An alternating treatment comparison of minimal and maximal opposition sound selection in Turkish phonological disorders. Clinical linguistics and phonetics, 24(8), 646-668.

Yalaz, K., Anlar, B., \& Bayoğlu, B. (2011). Denver II Gelişimsel Tarama Testi: Türkiye Standardizasyonu [Denver II Developmental Screening Test: Turkey standardization]. Ankara: Gelişimsel Çocuk Nörolojisi Derneği. 


\section{Appendix A}

Test items that have consonant phonemes and consonant clusters in word initial, syllable initial (WISI), withinword, syllable intial (WWSI), withinword, syllable final (WWSF) and word final, syllable final (WFSF) positions (Topbaş, 2006a).

\begin{tabular}{|c|c|c|c|c|}
\hline phoneme & WISI & WWSI & WWSF & WFSF \\
\hline$/ \mathrm{p} /$ & /pil/ 'battery' & /ka.pu/ 'door' & $\begin{array}{l}\text { /he.li.kop.ter/ } \\
\text { 'helicopter' }\end{array}$ & /ip/ 'rope' \\
\hline$/ \mathrm{b} /$ & /be.bec/ 'baby' & /a.ra.ba/ 'car' & /cib.rit/ 'match' & N/A \\
\hline$/ t /$ & /top/ 'ball' & /ja.tak/ 'bed' & /at.kw/ 'skarf' & /at/ 'horse' \\
\hline /d/ & /d $\varepsilon$.d $\varepsilon /$ 'g.father' & /rad.jo/ 'radio' & $\mathrm{N} / \mathrm{A}$ & $\mathrm{N} / \mathrm{A}$ \\
\hline$/ k /$ & /kuj/ 'bird' & / Jap.ka/ 'hat' & $\begin{array}{l}\text { /a.jak.ka.bu/ } \\
\text { 'shoe' }\end{array}$ & /ku.łak/ 'ear' \\
\hline /g/ & $\begin{array}{l}\text { /ga.ze.te/ } \\
\text { 'newspaper' }\end{array}$ & /ba.gaz/ 'trunk' & $\mathrm{N} / \mathrm{A}$ & N/A \\
\hline |c/ & /ci.tap/ 'book' & / $\varepsilon . c \varepsilon r /$ 'candy' & /عc.mec/ 'bread' & /сœ.pec/ 'dog' \\
\hline $\mid \mathrm{f} /$ & /fy.nef/ 'sun' & $\begin{array}{l}\text { /sy.pyr. fह/ } \\
\text { 'broom' }\end{array}$ & $\mathrm{N} / \mathrm{A}$ & N/A \\
\hline$/ \mathrm{m} /$ & /ma.sa/ 'table' & /El.ma/ 'apple' & /kam.jon/ 'truck' & /ka.lem/ 'pencil' \\
\hline$/ \mathrm{n} /$ & $\begin{array}{l}\text { /ni.ne/ } \\
\text { 'g.mother' }\end{array}$ & /aj.na/ 'mirror' & $\begin{array}{l}\text { /don.dur.ma/ } \\
\text { 'icecream' }\end{array}$ & /bu.run/ 'nose' \\
\hline /f/ & /fa:.re/ 'mouse' & $\begin{array}{l}\text { /te.le.fon/ } \\
\text { 'telephone' }\end{array}$ & /def.ter/'notebook' & $\begin{array}{l}\text { /fo.toy.raf/ } \\
\text { 'photo' }\end{array}$ \\
\hline$/ \mathrm{v} /$ & /va.zo/ 'vase' & /de.ve/ 'camel' & /tav.jan/ 'rabbit' & /عv/ 'house' \\
\hline $\mid s /$ & /syt/ 'milk' & /bi.sic.let/ 'bike' & /as.cer/ 'soldier' & $\begin{array}{l}\text { /ma.kas/ } \\
\text { 'scissors' }\end{array}$ \\
\hline$|z|$ & /zil/ 'bell' & /y.zym/ 'grapes' & /tfiz.me/ 'boots' & /kuz/ 'girl' \\
\hline $\mid \mathrm{s} /$ & / Ji. $\int \varepsilon /$ 'bottle' & $\begin{array}{l}\text { /ka.fuuk/ } \\
\text { 'spoon' }\end{array}$ & / Jif.man/ 'fat' & /kaf/ 'eyebrow' \\
\hline$|3|$ & /zi.let/ 'razor' & $\begin{array}{l}\text { /0.3ह/ 'nail } \\
\text { polish' }\end{array}$ & $\mathrm{N} / \mathrm{A}$ & /ruz/ 'lipstick' \\
\hline$/ \mathrm{t} / /$ & /t fo.dzuk/ 'child' & /tfitfec/ 'flower' & /yt $\int . j \varepsilon n /$ 'triangle' & /satJ/ 'hair' \\
\hline$/ d_{3} /$ & $\begin{array}{l}\text { /dza:.mi/ } \\
\text { 'mosque' }\end{array}$ & 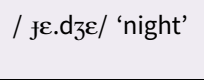 & $\mathrm{N} / \mathrm{A}$ & N/A \\
\hline$|r|$ & /re.sim/ 'picture' & /a.ru/ 'bee' & /par.mak/ 'finger' & /kar/ 'snow' \\
\hline /l/ & /lam.ba/ 'lamp' & $\begin{array}{l}\text { / fœz.lyc/ } \\
\text { 'glasses' }\end{array}$ & /عl.ma/ 'apple' & $\mid \varepsilon l /$ 'hand' \\
\hline$/ \mathrm{t} /$ & N/A & /ba.łuk/ 'fish' & /kot.tuk/ 'armchair' & /kot/ 'arm' \\
\hline /j/ & /ju. łan/ 'snake' & /a.ju// 'bear' & /baj.rak/ 'flag' & /aj/ 'moon' \\
\hline$/ \mathrm{h} /$ & /ha.vut]/ 'carrot' & $\begin{array}{l}\text { /si.hir.baz/ } \\
\text { 'magician' }\end{array}$ & /a.nah.tar/ 'key' & $\begin{array}{l}\text { /tim.sah/ } \\
\text { 'crocodile' }\end{array}$ \\
\hline
\end{tabular}


(Continued.)

\begin{tabular}{|c|c|c|c|c|}
\hline phoneme & WISI & WWSI & WWSF & WFSF \\
\hline$/ \mathrm{y} /$ & N/A & /a.yats/ 'tree' & /dyy.me/ 'button' & /jay/ 'butter' \\
\hline$/ \operatorname{tr} /$ & /tren/ 'train' & N/A & $\mathrm{N} / \mathrm{A}$ & N/A \\
\hline$/ \mathrm{rt} /$ & N/A & N/A & $\mathrm{N} / \mathrm{A}$ & $\begin{array}{c}\text { / Jort/ 'short } \\
\text { pants' }\end{array}$ \\
\hline /nt $\int /$ & N/A & $\mathrm{N} / \mathrm{A}$ & $\mathrm{N} / \mathrm{A}$ & /vint // 'crane' \\
\hline$/ \mathrm{rk} /$ & $\mathrm{N} / \mathrm{A}$ & N/A & $\mathrm{N} / \mathrm{A}$ & $\begin{array}{l}\text { /a.ta.tyrc/ } \\
\text { 'Atatürk' }\end{array}$ \\
\hline$/ / \mathrm{p} /$ & $\mathrm{N} / \mathrm{A}$ & N/A & $\mathrm{N} / \mathrm{A}$ & /kalp/ 'heart' \\
\hline /nk/ & $\mathrm{N} / \mathrm{A}$ & $\mathrm{N} / \mathrm{A}$ & N/A & /tank/ 'tank' \\
\hline$/ \mathrm{rf} /$ & $\mathrm{N} / \mathrm{A}$ & $\mathrm{N} / \mathrm{A}$ & $\mathrm{N} / \mathrm{A}$ & /zarf/ 'envelope' \\
\hline
\end{tabular}

Cite this article: Ketrez FN (2022). Consonant articulation and vocabulary size: Twins versus singletons. Journal of Child Language 49, 1242-1255. https://doi.org/10.1017/S0305000921000611 